УДК $811.112 ’ 38$

\title{
ОСОБЛИВОСТІ РОЗВИТКУ НІМЕЦЬКОГО МІСЬКОГО РОМАНУ
}

\author{
Мирослава Мельник \\ Львівський національний університет ім. Івана Франка \\ вул. Університетська 1, Львів, 79000, Україна \\ e-mail:mira.starster@gmail.com
}

Розглянуто особливості розвитку жанру міського роману в німецькій літературі, який набув особливої популярності в сучасному літературному процесі. Міський текст, що був популярний вже в епоху Середньовіччя, виокремився в жанр міського роману в період реалізму і зазнав значних змін у модернізмі. Сучасний міський роман, зберігши традиції модерністської течії, утім має свої характерні особливості.

Ключові слова: “людина-місто”, жанр міського роману, урбаністичний простір, суспільний розвиток.

Значне поширення жанру міського роману в Європі і Німеччині свідчить про актуальність звернення до теми відносин “людина-місто” та до питання, як зовнішній світ і просторове оточення людини здатні вплинути на ії внутрішній стан. Жанр міського роману набуває особливого масштабу в XX і XXI ст., що пояснюється перед усім актуалізацією феномена міста і впливом міської культури та урбанізованого простору на міського жителя.

Місто стало осередком політичних, економічних, культурних і суспільних процесів, символом розвитку людства та основним життєвим простором людей, тому важливість міста є очевидною і для письменників. Зокрема Н. Медніс, цитуючи російського дослідника Н. Анциферова, зазначає справедливість його твердження: “Всі дороги ведуть до міста. Міста - вузли, якими зв'язані економічні та соціальні процеси. Це центри тяжіння різноманітних сил, якими живе людське суспільство" [4, с. 1].

Проте звернення до міського тексту, зокрема до жанру міського роману, не є абсолютно новим для літературного процесу. Хоча тема відносин людини та міста зображується в багатьох творах, доречно звернути увагу на знакові етапи в розвитку жанру міського роману. Мета цієї розвідки полягає в тому, щоб прослідкувати, як змінився жанр міського роману в німецькій літературі, як саме змінилося значення міста, і яку роль воно тепер відіграє в житті людини.

Уперше тема міста і його значення для жителів піднімається вже в пізньому Середньовіччі. Розвиток німецьких міст спричинив зростання впливу німецьких бюргерів на тогочасне суспільне життя. Дослідники Е. Енгель, Е. Еннен, Ф. Г. Гіршман зображають особливості середньовічного міста та його поступальний характер $[7 ; 8 ; 9]$. Зокрема, Е. Еннен описує середньовічне місто так: “Als kompakte Silhouette heben sich die mauerumgürteten, dichtgebauten, von Türmen der Kirchen und Burgen übberragten Städte aus dem sie umgebenden

(C) Мельник М., 2014 
Land heraus" [8, с. 15]. А на думку Ф. Г. Гіршмана, середньовічні міста є відправними точками в розвитку європейської цивілізації, так званими "Kristallisationspunkte der Zivilisation ihrer Zeit" [9, c. 53]. Поступальний характер розвитку середньовічного міста відображається у виникненні нових різноманітних жанрів та форм середньовічної бюргерської літератури, наприклад, шванків, сатиричних повчальних віршів, народних пісень, майстерзангу, шпрухів, середньовічної духовної та світської драми.

Місто зображається в Середньовіччі осередком торгівлі та виробничих відносин; сюди стікаються різні верстви населення: ремісники, купці, клерки, лицарі, сільські бідняки тощо. Така “розмаїтість” населення зумовлює різноманітність міських утворень та суспільних відносин, на відміну від звичних однотипних селянських. Проте місто виступало об'єднувальним чинником для своїх мешканців, які жили за однаковим міським укладом і дотримувались звичаїв міста. Топографічні особливості середньовічного міста, яке зазвичай було оточене міцним захисним муром, викликали в жителів відчуття спокою, безпеки та соціальної рівності. Проте взаємовпливу людини та міста ще не бачимо в середньовічному літературному тексті, де увага зосереджувалася головно на соціальних та буденних проблемах міського населення.

Попри такий інтерес середньовічних авторів до міської тематики, власне жанр міського роману зароджується тільки в період реалізму. Такої думки дотримується і К. Ріга у дослідженні: "Von einem Stadtroman spricht man in der deutschen Literatur seit Fontane" [12, с. 27]. Виникнення цього жанру саме в період реалізму пояснюється тим, що роман стає найпоширенішим літературним жанром, в якому найповніше можна представити мотив міста, яке за своєю сутністю, як і роман, є комплексним, багатошаровим утворенням. Подруге, тематично німецький реалізм зображає буденне життя та проблеми бюргерів. Цей період характеризується детальним описом реальності, що оточує людину, та високим психологізмом, що виявляється в аналізі щоденних людських проблем і виокремленні закономірностей між людиною і суспільством, а також становленням “великого міста", внаслідок чого виникають лондонські романи, берлінські, петербурзькі, віденські тощо. Окрім того, реалізму характерна поява нового літературного героя, який прагне утвердити своє соціальне положення в новому міському середовищі. Тому відносини людини з соціальним оточенням і міським суспільством виходять на передній план, адже реалісти осягали сутність людини саме через час, простір та соціальні відносини.

Літературна традиція жанру німецького міського роману заснована на творах Теодора Фонтане (1819-1898) та Вільгельма Раабе (1831-1910). У творах Т. Фонтане особливо чітко бачимо емоційну важливість міського оточення - головний елемент його праць. Простір відіграє символічну роль і відображає потенційне значення зовнішнього світу та оточуючих предметів для індивіда, про що зазначав В. Е. Рост [13]. Значну роль у творчості Т. Фонтане відіграють так звані берлінські романи, і початком цього циклу вважається повість “Грішниця” (“L'Adültera”, 1882). Розчарування тогочасними буржуазними порядками, прагненням до розкоші, до соціального та публічного визнання змушують головну героїню Мелані ван дер Штраатен покинути свого чоловіка, втекти до Італії зі своїм коханцем Рубеном і вдруге там одружитися. Проте сум за Берліном змушує Мелані повернутися назад, де новостворена сім'я зазнає серйозних фінансових труднощів, оскільки більшість оточення Мелані відвернулось від неї через її ганебний вчинок і зраду чоловікові. Незважаючи на те, що спілкуванням з нею нехтує більшість їі оточення, головна героїня все ж щаслива, адже попередній шлюб приносив їй тільки розчарування життєвими та моральними устроями 
тогочасного суспільства. Хоча Т. Фонтане нейтрально викладає перебіг подій, протиставлення багатіям простоти і в той же час благородства звичайних людей дозволяє читачеві зрозуміти негативне ставлення автора до буржуазних порядків, що передається ним перш за все через особисту кризу героїні Мелані, доля якої частково повторюється в романі $\mathrm{T}$. Фонтане “Еффі Бріст” (“Еffi Briest”, 1896).

В іншому творі з циклу берлінських романів “Пані Женні Трайбель”(“Frau Jenny Treibel", 1891) T. Фонтане критикує вади буржуазного суспільства та вміння аристократичного класу пристосовуватися до нового життя. Зокрема в цьому творі відтворена дуалістичність тогочасного бюргерства: Т. Фонтане виокремлює Großbürger, які збагатилися завдяки торгівлі та виробництву і тепер будь-що прагнуть надзвичайного багатства та розкоші (наприклад, Женні Трайбель); їм протиставляються Bildungsbürger — освічена, проте менш процвітаюча частина суспільства (наприклад, Вілібальд Шмідт та його донька). Таке протиставлення особливо загострює увагу читача на вадах та недоліках Großbürger, основної верстви тогочасного берлінського суспільства.

Варто зазначити, що реалізм уже не лише торкається проблем міських жителів, але на цьому етапі вимальовується певний зв'язок “людини” та “міста”. Дослідник В. Е. Рост наголошує на тому, що Т. Фонтане у своїх творах звертається до сутності людської природи та до iii зовнішнього оточення, наголошуючи на взаємозв'язку цих понять: “...erblickt Fontane seine dichterische Aufgabe gerade in der Schilderung des Menschen, den er bis in die feinsten Regungen der Seele mit eigenartigen Vorzügen und auch mit liebenswürdigen Schwächen darzustellen weiß; er lässt aber in die plastische Wiedergabe des Lokalen, die sich nie im Nachzeichen von Äußerlichkeiten verliert, nicht weniger Liebe einströmen" [13].

У його творах простір та навколишнє середовище займають одну з найпровідніших ролей, вони допомагають автору певною мірою розкрити сутність людської природи, зобразити психологічний стан людини та осягнути ії глибину. На фоні міста він зображає типові для Берліна характери, що розкриваються в головних героях його творів. Акцентуючи психологічні особливості впливу зовнішнього оточення на людину, Т. Фонтане показує, як людина може розкритись у своїх взаємозв'язках із суспільством. Ідентифікаторами статусу, ментальності та характеру головних героїв часто виступають численні та детальні описи міста, вулиць, будинків, кімнат та інтер'єрів. Місто у творах Т. Фонтане виступає просторовим оточенням і водночас частиною суспільства. Опис міста слугує лише фоном для зображення характеру героїв та їхньої психологічної суті, місто виступає лише як частина хронотопу твору. Попри це, провідне значення міста в житті людини вже починає викристалізовуватися, про що свідчить і той факт, що з творчістю Т. Фонтане в німецькій літературі започатковується жанр Großstadtliteratur, що дозволяє читачеві сприймати Берлін як один із провідних зразків “великого міста”.

Інший представник німецького реалізму Вільгельм Раабе надає мотиву міста виключно негативної конотації, що свідчить про зростання впливу великого міста на людину, яка ще не здатна осягнути значні зміни і тому досить часто сприймає велике місто як втілення зла. Найяскравішим зразком міського роману у В. Раабе є “Хроніка гороб'ячого провулка" (“Chronik der Sperlingsgasse”, 1856). Безліч сюжетних ліній, героїв, їхніх спогадів та думок об’єднані ідилічністю маленької вулички Шперлінггассе, яка змодельована за зразком однієї 3 вулиць Берліна. Така обмеженість літературного простору є цілком зрозумілою, адже у своїх творах В. Раабе жорстоко критикує місто, осередок капіталізації та індустріалізації. Про таку позицію автора зазначала у своїй праці російська дослідниця Ю. Литовченко [3]. 
Вона наголошувала на тому, що В. Раабе намагається з великого міста виокремити “тихий казковий куточок”, віддалений від зовсім іншого тогочасного Берліна, - 3 широкими вулицями та площами, з нестримним потоком людей і постійними змінами. Здається, що автор вважає за потрібне не описувати цю частину міста, так ніби їі взагалі не існує. В. Раабе лише згадує про існування нових кварталів, які, на його думку, бездушні і пусті, адже люди 3 розвитком міста втрачають можливість повноцінного людського спілкування - велике місто забирає цю можливість у людей [3]. В. Раабе також негативно ставиться і до інших проявів індустріалізації, неодмінно пов'язуючи цей процес із самотністю людини та навіть смертністю. Картина світу, створена В. Раабе в його творах, викриває недосконалість людської цивілізації, в основу якої покладено не моральні принципи, а лише науково-технічні досягнення та індустріальний розвиток.

“Велике місто" нестримним темпом поглинає такі “острови минулого” як Шперлінггассе, і тому його образ виступає вкрай негативним у романах В. Раабе. Місто у В. Раабе, як невідривна частина процесу індустріалізації, втрачає будь-який моральний вигляд і перетворюється на механізм, який знищує людські взаємини і саму людину. В. Раабе ототожнює стрімкий розвиток міста з безповоротним рухом цивілізації в бік аморальності та безликості. Саме тому будь-яка спроба жити та існувати поза межами “островів минулого” асоціюється у В. Раабе з втратою людяності та основних моральних принципів і виникненням нових суспільних проблем.

Наступний знаковий етап розвитку міського роману в німецькій літературі припадає на епоху модернізму і представлений перш за все романом Альфреда Дебліна “Берлін. Александерплатц" (“Berlin Alexanderplatz”, 1929), який тепер вважається одним із класичних зразків міського роману. Епоха модернізму характеризується кризою людської свідомості, тому людина намагається знайти своє “я” не тільки в собі, але й у своєму оточенні. Внаслідок цього література також переживає значні зміни - відбувається перегляд естетичних цінностей, виникає безліч нових літературних течій, змінюється тематика і форма викладу (наприклад, метод монтажу, який використав і А. Деблін у своєму романі). Попри головний акцент на сутність людини, значення міста зростає, адже воно стає суспільним, політичним, індустріальним та культурним осередком, основою нового суспільства. Тепер міський роман набуває особливої популярності, а місто в ньому починає співіснувати разом з головними героями та взаємодіяти з ними.

А. Деблін на прикладі Франца Біберкопфа показує, як тогочасна людина вибудовує свої стосунки з містом, і як вони взаємодіють між собою. Початок роману характеризується досить негативним ставленням Франца, який виходить із в'язниці, до свого Берліна, що зазнав разючих змін за час його відсутності. Страх перед висотними будинками, котрі готові от-от впасти йому на голову, його пригніченість серед численних кав'ярень, магазинів, трамваїв та будинків свідчить про розгубленість перед життям. Франц, який не має сім'ї та не знає, куди податися після звільнення, блукає вулицями Берліна і не впізнає його - виявляється, місто не переставало жити своїм життям і розвиватись.

Проте з розвитком сюжету зніяковілість Франца поступово зникає, місто ніби поглинає його. Читач разом з ним прогулюється Берліном - авторові вдається передати звуки трамваїв, що ніби переміщують читача з одного місця подій до іншого; фрагменти розмов продавців різноманітних крамниць створюють атмосферу торговельного міста; численні ресторани, кафе та кав'ярні стають головними осередками соціального життя людей: “Усе це відтворює особливу атмосферу тих часів, коли “спів грамофона” наповнював берлінські 
оселі, а трамвай був найсучаснішим досягненням техніки, та свідчить про вміння письменника зображати не саме місто, а “життя в контексті створеної в місті культури” [1, с. 8].

Техніка монтажу дозволяє А. Дебліну викликати в читача відчуття одночасного перебігу кількох подій у різних місцях - життя в місті вирує. Багатоголосся, двоїста природа оповіді та викладу погляду героя в романі є головними особливостями роману-монтажу, що знаходять свій вияв у постійній зміні оповіді “всезнаючого” автора на модерністського, який не здатен охопити дійсність своєю думкою; багатоголосся знаходить свій вияв у переплетінні голосу Франца (внутрішній монолог та потік свідомості) з голосами автора, інших героїв роману та голосом міста [2].

Складається враження, що історія Франца Біберкопфа відходить на задній план, а життя міста набуває більш важливого значення, про що свідчить і сама назва роману. На відміну від свого попередника В. Раабе, А. Деблін зображає місто як найголовнішу частину суспільства, яке не тільки не заважає комунікації людей, а навпаки створює іiі. Ф. Клотц у своєму дослідженні називає Берлін у творі Дебліна “Agon Stadt” [10]. 3 грецької “агон” позначає місце зібрання для спортивних і розумових змагань. Тогочасний Берлін став містом зібрання різноманітних людей, які по своїй суті унікальні, проте об'єднані приналежністю до нього. Адже людина, яку повністю поглинуло міське життя, легше підтримує соціальні контакти завдяки зустрічам у кафе, побіжним розмовам у магазинах, почутій інформації серед перехожих тощо. Такий постійний обіг інформації в місті та постійне спілкування людини з оточуючим середовищем дає змогу людині самоідентифікуватися, віднайти своє “я”.

Відтепер місто $є$ чинником самоідентифікації людини, воно стає рівноправним членом опозиції “людина-місто”. 3 початку XX ст. можна також говорити про свідому урбанізацію простору людиною, що пояснюється важливістю міста як онтологічного підгрунтя існування сучасної людини. В. Топоров у своїй праці наголошує на значенні феномена сучасного міста: “З появою міста людина вступила в новий спосіб існування, який, виходячи 3 попередніх уявлень та мірок, не міг не здаватися парадоксальним і фантастичним [...] I втім людина пов'язала себе саме 3 містом, тому що в феномені міста вона знайшла для себе найбільш адекватну форму існування, хоча й пов'язану з великим ризиком" [5, с. 121]. Безпосередній зв'язок міста і людини та урбанізація навколишнього простору спричинили подальший розвиток жанру міського роману.

Сучасний німецький міський роман наслідує традиції А. Дебліна, нерідко використовуючи техніку монтажу, як один із провідних засобів зображення та опису навколишньої дійсності. Проте з часів Дебліна цей жанр зазнає певних змін. Перш за все, читач $є$ співспоглядачем разом із протагоністом роману - він активно втягнутий у розвиток подій i повинен сам вирішувати, яким для нього є те чи інше місто і в якому світлі його сприймати. Найсуттєвіша зміна в жанрі міського роману стосується самого героя, адже з'являється тип “фланер” - людина, яка прогулюється містом без певної мети, тому інколи в читача складається враження, що це іiї єдине заняття (наприклад, фланер у творах В. Генаціно). Найгрунтовніше до дослідження мотиву фланерства в сучасному міському романі підходить $\mathrm{X}$. Ноймаєр [11]. У той час як берлінець у А. Дебліна постійно відчуває цейтнот, кудись поспішає і лише побіжно зауважує, що відбувається навколо нього (зображення подій у житті Франца перемішане фрагментами з життя міста, різноманітних розмов, назв вивісок магазинів та звуками трамвая), герой сучасного міського роману проводить безліч часу, просто спостерігаючи за містом та його мешканцями. Він бачить найдрібніші подробиці та деталі, навіть у зовнішньому вигляді перехожих. На думку іншого дослідника, В. Беньяміна, 
цей герой не просто так вештається містом, він перебуває в пошуках свого місця в новому суспільстві: "Der Flaneur steht noch auf der Schwelle der Großstadt ... Er sucht sich sein Asyl in der Menge" [6, с. 54]

Сучасний німецький міський роман засновується на літературних традиціях реалізму та модернізму. Попри традиційність цього жанру, він тяжіє до новаторства та зміни перспективи, тематики та форми викладу. Місто в сучасному романі тепер асоціюється 3 величиною, густотою, різноманітністю і багатоголоссям, що знаходить своє відображення в композиційних та структурних особливостях цього жанру. Це дає змогу сучасним письменникам зображувати місто як головний осередок життя у власній, притаманній їм манері.

1. Богданова О. I. Ольфакторний та звуковий аспекти образу міста в романі А. Дьобліна “Берлін, Александерплатц" / О. І.Богданова // Обрії сучасної філології: збірка наукових праць / Луганський державний інститут культури та мистецтва. - Випуск 4. - Луганськ : Видавництво ЛДІКМ. - 2011. - С. 6-11. 2. Драч И. Г. Поэтика романа-монтажа : автореф. дис. канд. фил. наук: спец. ВАК 10.01.08 “Теория литературы, текстология”/ Драч Инна Геннадьевна. - Москва, 2013. - 23 С. 3. Литовченко Ю. Поэтика романов В. Раабе 1890-х гг.: “Штопфкухен”, “Протоколы городка Фюгельзанг”/ Литовченко Юлия Борисовна// Санкт-Петербург. - 2008. - 237 С. 4. Меднис Н. Венеция в русской литературе [Електронний ресурс] / Н.Е.Меднис// Новосибирск : Издательство Новосибирского университета. - 1999. - 392 С. Режим доступу : http://profilib.com/ chtenie/147555/nina-mednis-venetsiya-v-russkoy-literature.php. 5. Топоров B. Н. Текст города-девы и города-блудницы в мифологическом аспекте / В. Н. Топоров // Исследования по структуре текста. - М: Наука. - 1987. - С. 121-132. 6. Benjamin W. Das Passagen-Werk/ Rolf Tiedemann (Hrsg.)/ Frankfurt am Main : Suhrkamp. - 1983. - 1354 S. 7. Engel E. Städtisches Leben im Mittelalter/ Evamaria Engel// Böhlau. - 2006. - 465 S. 8. Ennen E. Die europäische Stadt des Mittelalters/ Edith Ennen // Vandenhoeck\&Ruprecht. - 1987. - 349 S. 9. Hirschmann F. Die Stadt im Mittelalter/ Frank G. Hirschmann// Oldenbourg Verlag. - 2009. - 146 S. 10. Klotz V. Die erzählte Stadt: ein Sujet als Herausforderung des Romans von Lesage bis Döblin/ Volker Klotz // München. - 1969. 11. Neumeyer H. Der Flaneur : Konzeptionen der Moderne/ Harald Neumeyer// Königshausen \& Neumann. - 1999. - 420 S. 12. Riha K. Die Beschreibung der "Großen Stadt". Zur Entstehung des Großstadtmotivs in der deutschen Literatur (ca. 1750-ca. 1850) / Karl Riha // Bad Homburg v.d.H., Berlin, Zurich: Gehlen. - 1970. 13. Rost W. E. Örtlichkeit und Schauplatz in Fontanes Werken / Wolfgang E. Rost // Berlin : Walter de Gruyter \& Co. $-1931 .-157$ S.

\title{
ОСОБЕННОСТИ РАЗВИТИЯ НЕМЕЦКОГО ГОРОДСКОГО РОМАНА
}

\author{
Мирослава Мельник
}

\author{
Львовский национальный университет имени Ивана Франко \\ ул. Университетская 1, Львов, 79000, Украина \\ e-mail:mira.starster@gmail.com
}

Рассмотрены особенности развития жанра городского романа в немецкой литературе, который стал особенно популярным в современном литературном процессе. Городской текст, популярний уже в епоху Средневековья, сформировался в жанр городского романа 
в период реализма и подвергся значительным изменениям в модернизме. Современный городской роман, унаследовав традиции модернисткого направления, тем не менее имеет свои характерные особесности.

Ключевые слова: “человек-город”, городской роман, урбанистическое пространство, общественное развитие

\title{
THE PECULIARITIES IN THE DEVELOPMENT OF THE GERMAN URBAN NOVEL
}

\author{
Myroslava Melnyk \\ Ivan Franko National University of Lviv \\ 1, Universytetska St., Lviv, 79000, Ukraine \\ e-mail:mira.starster@gmail.com
}

This article is devoted to the peculiarities in the development of the German urban novel that has become especially popular in the present-day literary process. The urban text, which was already popular in the medieval times, was formed into the genre of the urban novel and faced significant changes during modernism. The present-day urban novel, which inherited traditions of modernism, has nonetheless its own specific features.

Keywords: "human-city", urban novel, urbanistic space, social development

Стаття надійшла до редколегії 21.05.2014 p.
Статтю прийнято до друку 21.09.2014 p. 